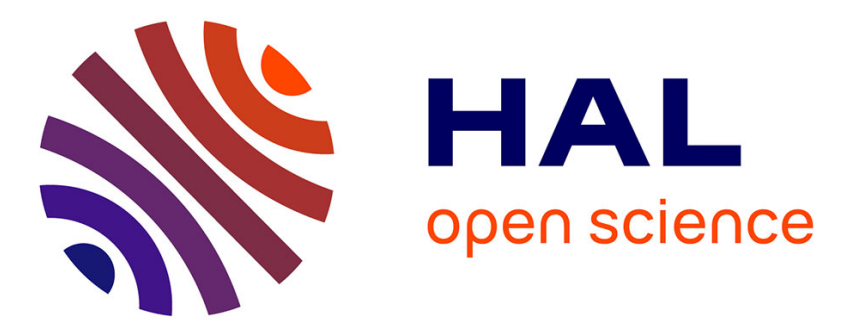

\title{
COMPARISON BETWEEN TRADITIONAL MINERALOGICAL AND COMPUTERIZED RATIONAL ANALYSIS OF CERAMIC RAW MATERIALS
}

\author{
B. Fabri, C. Fiori, A. Krajewski, R. Valmori, A. Tenaglia
}

\section{To cite this version:}

B. Fabri, C. Fiori, A. Krajewski, R. Valmori, A. Tenaglia. COMPARISON BETWEEN TRADITIONAL MINERALOGICAL AND COMPUTERIZED RATIONAL ANALYSIS OF CERAMIC RAW MATERIALS. Journal de Physique Colloques, 1986, 47 (C1), pp.C1-57-C1-62. 10.1051/jphyscol:1986109 . jpa-00225493

\section{HAL Id: jpa-00225493 https://hal.science/jpa-00225493}

Submitted on 1 Jan 1986

HAL is a multi-disciplinary open access archive for the deposit and dissemination of scientific research documents, whether they are published or not. The documents may come from teaching and research institutions in France or abroad, or from public or private research centers.
L'archive ouverte pluridisciplinaire $\mathbf{H A L}$, est destinée au dépôt et à la diffusion de documents scientifiques de niveau recherche, publiés ou non, émanant des établissements d'enseignement et de recherche français ou étrangers, des laboratoires publics ou privés. 


\title{
COMPARISON BETWEEN TRADITIONAL MINERALOGICAL AND COMPUTERIZED RATIONAL ANALYSIS OF CERAMIC RAW MATERIALS
}

\author{
B. FABRI, C. FIORI, A. KRAJEWSKI, R. VALMORI and A. TENAGLIA* \\ C.N.R., Istituto di Ricerche Tecnologiche per la Ceramica, Via \\ Granarolo, 64, I-48018 Faenza, Italy \\ * Centro Ceramico, Via Martelli, 26, I-40138 Bologna, Italy
}

\begin{abstract}
Résumé - Les analyses minéralogiques quantitatives complètes sur 45 matières premières céramiques ont été conduites suivant une méthode qui utilise le calcul indirect sur ordinateur à partir de la composition chimique. En comparant ces résultats avec les résultats obtenus avec différentes méthodes analytiques, on discute la validité de l'analyse rationelle par ordinateur en ce qui concerne la fiabilité et les applications dans le contrôle de routine des matières premières pour l'industrie céramique.

Abstract - Complete quantitative mineralogical analyses of 45 ceramic raw materials were carried out following a computerized procedure based on recalculation from the chemical composition. Comparing the results with others from different analytical methods, this computerized rational analysis was discussed regard to its reliability and application to routine control of raw materials in ceramic processes.
\end{abstract}

\section{I - INTRODUCTION}

In a previous work $/ 1 \%$, a computerized procedure of rational analys is has been proposed to obtain the complete mineralogical composition of ceramic raw materials, particularly the clayish ones. In the present paper data obtained jy this method are compared with those resulting for the same samples analysed by other methods in different laboratories. The samples are subdivided into three principal groups according both to their composition and to the source of data. A first group consists of ten granite samples; a second group consists of ten calcareous illiticchloritic clays for heavy-clay production; the third group consists of twenty-five smectitic or kaolinitic clays used in the ceramic industry. The chemical and mineralogical compositions both of the granite samples and of the calcareous clays have been found in the scientific literature $12,3 /$, while the reference data for the materials of the third group have been determined by us on purpose.

\section{II - ANALYTICAL METHODS}

A summarized description of the analytical methods used to obtain the rational data and the reference ones is reported. A more exhaustive explanation of these methods 
can be found in the specific papers $/ 1,2,3 /$.

Computerized rational data

The complete mineralogical compositions are calculated from the chemical data by a computerized procedure; the minerals to be calculated are selected on the basis of a qualitative analysis by x-ray diffraction. A machematical system is set up by combining the equations which describe, for each chemical element, the total contribution from the minerals to be calculated; the system is always completed by an equation which establishes that the sum of the amounts of each of the minerals is equal to one hundred:

$$
\begin{aligned}
& x_{1} a_{11}+x_{2} a_{12}+\ldots \ldots+x_{n} a_{1 n}=A_{1} \\
& x_{1} a_{21}+x_{2} a_{22}+\ldots \ldots+x_{n} a_{2 n}=A_{2} \\
& \ldots \ldots \ldots \ldots \ldots \ldots \ldots \ldots \ldots \ldots \\
& x_{1} a_{m 1}+x_{2} a_{m 2}+\ldots \ldots+x_{n} a_{m n}=A_{m} \\
& x_{1} M_{1}+x_{2} M_{2}+\ldots \ldots+x_{n} M_{n}+z=100
\end{aligned}
$$

where:

$x_{j}=$ mole quantity of the mineral phase $\underline{j}$ to be calculated;

$a_{i j}=$ stoichiometric coefficient correspondent to the mole quantity of each element $i$ in one mole of the mineral phase $j$, the composition of which is chosen as resulting from its theoretical formula; $\begin{aligned} A_{i}= & \text { mole quantity of each element } i \text { calculated from the quantitative chemical com- } \\ & \text { position of the raw material; }\end{aligned}$

$M_{j}=$ molecular weight of the mineral phase $\underline{j}$;

$Z$ = percent amount by weight assumed for accessory minerals.

The system is solved by the least squares method, but the solution is accepted only if the discrepancies between the oxide concentrations, recalculated and chemically determined respectively, are not higher than a predetermined value. To increase the probability of obtaining a reliable solution, for each sample a lot of systems are defined varying both the composition assigned to chlorite and illite, if they are present, and the amount of accessory minerals. For smectite, calculation is normally carried out with the chemical composition of montmorilionite, but one may select beidellite, nontronite or saponite if there are evidences from chemical and $x$-ray data. In this way, a lot of reliable solutions are often obtained; then the average solution is finally retained as the composition of the sample.

Reference data

The complete mineralogical compositions of the granite samples were determined by a point-counting method on thin sections at the mineralogical microscope $/ 2 /$. For the calcareous clays of the second group of samples considered, quantitative mineralogical data are available only for quartz and calcite, being dolomite always less than $5 \%$. These values were determined by $x$-ray diffraction techniques $/ 3 /$. The twenty-five samples constituting the third group have been analysed by us in order to determine the quantitative composition of the clayish fraction (less than $2 \mu m$ ) adopting the following $x$-ray procedure. After separation of a fraction less than $2 \mu \mathrm{m}$, on an oriented sample three $x$-ray analyses are performed: on natural, on $\mathrm{gly}-$ colated (at $45^{\circ} \mathrm{C}$ per 24 hours) and on heated (at $550^{\circ} \mathrm{C}$ per 2 hours) sample. From the area of the peaks on the diffractogram of the glycolated sample, the relative amounts of the clay minerals are then calculated $/ 4 /$. To allow a comparison, for 
each sample the total amount of clayish minerals determined by the so-called reference procedure has been imposed to be equal to that resulting from the computerized rational analysis, which gives a complete mineralogical composition of the untreated sample. Other than in the original papers, the chemical and mineralogical data of the granites and of the calcareous clays are reported in an internal report of
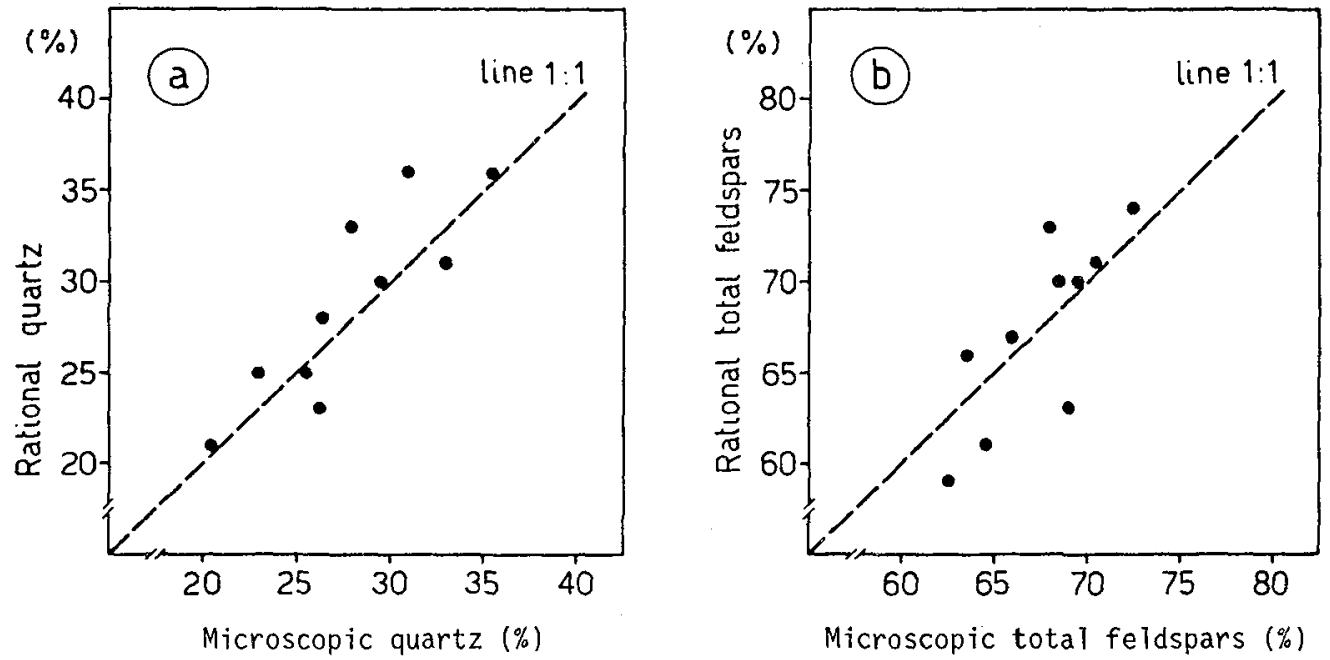

Fig. 1 - Comparison between microscopic and rational amounts of quartz (a) and total feldspars (b) in granite samples. Reference data from Paganel1i, Tiburtini $12 /$.

IRTEC; in that report all the data relative to the other twenty-five clay raw materials are also iisted $/ /$.

\section{III - RESULTS AND DISCUSSION}

For each sample only data which can be useful for discussion are shown in this paper; ali the others can be found in the above-mentioned internal report $\%$

Granites

The granites are made up of quartz, perthite, plagioclase and other minor minerals, mainly mafic. Perthite is a potassic feldspar with intergrown albite (i.e. sodium feldsparl, which formed during cooling from primary solid solution between the feldspars of potassium and sodium. Plagioclase is a solid solution of the feldspars of sodium and calcium. By a point-counting method, quartz, perthite and plagioclase can be determined, while through the rational analysis, in addition to quartz, one can calculate the amount of the single terms of the feldspar group; i.e. K-, Naand Ca-feldspar respectively. Therefore the comparison between the data obtained by the two methods can be made considering the amount of quartz and the total amount of feldspars (Fig. la and ib respectively). In both cases the correlation between microscopic and rational computerized data is quite evident, since any point in the diagram is not too far from the $?$ ine $1: ?$.

Calcareous clays

The ten calcareous clay samples are very similar among themselves and they are made of quartz, Na-feldspar, carbonates (mainly calcite), illite, chlorite and iron oxides. The comparison between rational and reference data for quartz, calcite and dolomite is reported in Table 1. Our computed dolomite amounts range from 4 to $8 \%$, 
only slighly above the indicative ones of literature. The calculated calcite concentration very well agree with those determined by an x-ray method; in fact the differences are never higher than $3 \%$. The discrepancies for quartz are bigger; however the results are very good for technological and applicative purposes.

Table 1 - Quantitative mineralogical data for calcareous clays whose total composition includes quartz, Na-feldspar, carbonates, illite, chlorite and iron oxides.

\begin{tabular}{|c|c|c|c|c|c|c|c|c|c|c|c|}
\hline \multirow{2}{*}{\multicolumn{2}{|c|}{ mineral phase }} & \multicolumn{10}{|c|}{ sample $n$. } \\
\hline & & 26 & 27 & 28 & 29 & 30 & 32 & 33 & 34 & 35 & 36 \\
\hline \multirow{2}{*}{ quartz } & 1 & 35 & 34 & 36 & 35 & 27 & 25 & 24 & 22 & 27 & 26 \\
\hline & 12 & 28.0 & 29.5 & 300 & 42.0 & 33.5 & 21.0 & 16.0 & 20.0 & 30.5 & 26.0 \\
\hline \multirow{2}{*}{ calcite } & 1 & 16 & 18 & 17 & 17 & 17 & 16 & 16 & 19 & 15 & 16 \\
\hline & 2 & 18 & 16 & 15 & 15 & 16 & 17 & 18 & 16 & 17 & 17 \\
\hline \multirow{2}{*}{ dolomite } & 1 & 6 & - & 5 & 4 & 6 & 7 & 8 & - & 7 & 7 \\
\hline & 2 & $<5$ & - & $<5$ & $<5$ & $<5$ & $<5$ & $<5$ & - & $<5$ & $<5$ \\
\hline
\end{tabular}

$1=$ rational data: 2 = reference data $/ 3 /$

Kaolinitic and smectitic clays

All the data obtained by both the rational method and the so-called reference procedure are listed in Table 2. If we consider chlorite, we can note that its amounts are always low; notwithstanding this, it is evident that rational vaiues result systematically higher than those determined in the fractions less than 2 um. In our opinion, this depends mainly on a relative reduction of the chlorite content due to the granulometrical selection. Also the rational data for illite are generally higher than the reference ones, but there is a good correlation between the two sets of data, as it may be seen in Fig. $2 \mathrm{a}$. Furthermore, it is evident that the points representing the samples without illite/smectite interlayered phases (open circles) on an average fit the line $1: 1$. So, the systematic differences for illite concentrations are due to the presence of an interlayered mineral, which cannot be considered as a computable phase in the rational analysis. This is evident from the diagram of the difference between rational and $x$-ray $i \mathrm{ilite}$ versus the interlayer amount (Fig. 2b), with the only exception of some samples, particularly those lacking of kaolinite (open circles). For these last samples, the rational smectite values result higher than the reference ones (see samples $n$. 1 , 2 and 7 in Table 2); in all the other cases, the rational data for smectite are casualiy higher or lower than the others: this means that there are no systematic discrepancies. No systematic differences seem to exist between the two sets of data obtained for kaolinite, also if in the most cases the rational data are the highest ones.

\section{IV - CONCLUSIONS}

The computerized method for the rational analysis of the mineralogical composition of ceramic raw materials, besides to guarantee reproducible and comparable results, gives data that are in good agreement with those coming from other analytical procedures, and does not need of any weighting scheme to give better solutions $/ 6 /$. It obviously shows some limits mainly due to the impossibility of defining the com- 
position of amorphous phases and/or of specific mineral combinations (mixed-layer minerals). However, this method speedly gives a picture of the quantitative mineralogical parameters of each sampling. This is useful to investigate possible correlations between mineralogical compositions and technological properties, at a sta-

Table 2 - Quantitative mineralogical data for kaolinitic or smectitic clays.

\begin{tabular}{|c|c|c|c|c|c|c|c|c|c|c|c|c|c|}
\hline \multirow{2}{*}{ 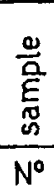 } & \multirow{2}{*}{$\frac{\stackrel{N}{\frac{N}{\sigma}}}{\stackrel{\frac{\sigma}{\sigma}}{1}}$} & \multirow{2}{*}{ 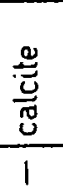 } & \multicolumn{2}{|c|}{ illite } & \multicolumn{2}{|c|}{ smectite } & \multirow{2}{*}{ 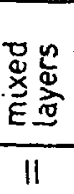 } & \multicolumn{2}{|c|}{ kaolinite } & \multicolumn{2}{|c|}{ chlorite } & \multirow{2}{*}{ 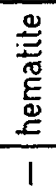 } & \multirow{2}{*}{$\frac{\frac{n}{2}}{\frac{\tilde{L}}{\Delta}}$} \\
\hline & & & 1 & II & 1 & II & & 1 & II & 1 & II & & \\
\hline 1 & 21 & 6 & 20 & 17 & 44 & 31 & 16 & - & - & - & - & 7 & 2 \\
\hline 2 & 22 & - & 22 & 13 & 48 & 37 & 20 & - & - & - & - & 6 & 2 \\
\hline 3 & 18 & 17 & 18 & 4 & 24 & 25 & 20 & 6 & 5 & 9 & 3 & 5 & 3 \\
\hline 4 & 23 & $9 *$ & 27 & 13 & 15 & 16 & 20 & 9 & 6 & 8 & 4 & 7 & 2 \\
\hline 5 & 24 & - & 35 & 16 & 18 & 25 & 19 & 7 & 6 & 9 & 3 & 5 & 2 \\
\hline 7 & 25 & 2 & 22 & 13 & 39 & 29 & 19 & - & - & - & - & 8 & 4 \\
\hline 8 & 25 & 18 & 21 & 11 & 13 & 16 & 17 & 4 & 2 & 11 & 3 & 3 & 5 \\
\hline 9 & 23 & 7 & 29 & 14 & 14 & 24 & 17 & 11 & 4 & 8 & 3 & 5 & 3 \\
\hline 10 & 23 & 14 & 26 & 14 & 13 & 17 & 17 & 8 & 5 & 10 & 4 & 4 & 2 \\
\hline 11 & 25 & 11 & 27 & 13 & 13 & 21 & 16 & 8 & 3 & 8 & 3 & 5 & 3 \\
\hline 12 & 21 & 3 & 30 & 27 & 16 & 7 & 15 & 13 & 12 & 13 & 11 & - & 4 \\
\hline 13 & 20 & $16 *$ & 31 & 25 & - & - & 7 & 3 & 3 & 7 & 6 & 4 & $19+$ \\
\hline 16 & 30 & $9 *$ & 29 & 20 & 14 & 15 & 10 & 6 & 6 & 6 & 4 & 4 & 2 \\
\hline 17 & 34 & 6 & 28 & 19 & 12 & 11 & 12 & 3 & 5 & 9 & 5 & 3 & 5 \\
\hline 18 & 32 & $8 *$ & 27 & 18 & 15 & 14 & 12 & 5 & 4 & 6 & 3 & 3 & 4 \\
\hline 19 & 30 & - & 29 & 24 & 23 & 16 & 8 & 3 & 8 & 7 & 6 & 4 & 4 \\
\hline 20 & 42 & - & 41 & 33 & - & - & 5 & 9 & 12 & - & - & 5 & 3 \\
\hline 21 & 28 & - & 38 & 48 & - & - & - & 23 & 13 & - & - & 8 & 3 \\
\hline 22 & 23 & - & 46 & 37 & - & - & - & 19 & 28 & - & - & 8 & 4 \\
\hline 23 & 28 & - & 41 & 42 & - & - & - & 21 & 20 & - & - & 8 & 2 \\
\hline 24 & 25 & - & 49 & 38 & - & - & 12 & 14 & 13 & - & - & 9 & 3 \\
\hline 25 & 27 & - & 49 & 44 & - & - & 6 & 13 & 12 & - & - & 7 & 4 \\
\hline 26 & 6 & - & 48 & 56 & - & - & - & 32 & 24 & - & - & 10 & 4 \\
\hline 27 & 7 & - & 46 & 27 & 19 & 26 & 17 & 17 & 11 & 3 & 4 & 6 & 2 \\
\hline 28 & 29 & 17 & 18 & 12 & 15 & 13 & 9 & 5 & 4 & - & - & 4 & $12+$ \\
\hline
\end{tabular}

$1=$ rational data: $\|=X$-ray data for the fraction less than $2 \mu \mathrm{m}:+=\mathrm{Na}-$ feldspar $16 \%$ and other $3 \% ; \ddagger=\mathrm{Na}-$ feldspar $9 \%$ and $\mathrm{K}$-feldspar $3 \% ; *$ = dolomite: $*$ calcite $6 \%$ and dolomite $10 \%$.

tistical leve1, of both green and fired clay-based products. The procedure is simple and rapid, so it may be conveniently adopted by ceramic industries and more generally by factories involved in clay minerals mining and refining. Furthermore, the accuracy is high enough to ensure successful applications for applied studies and researches in fields also other than ceramic technology. 

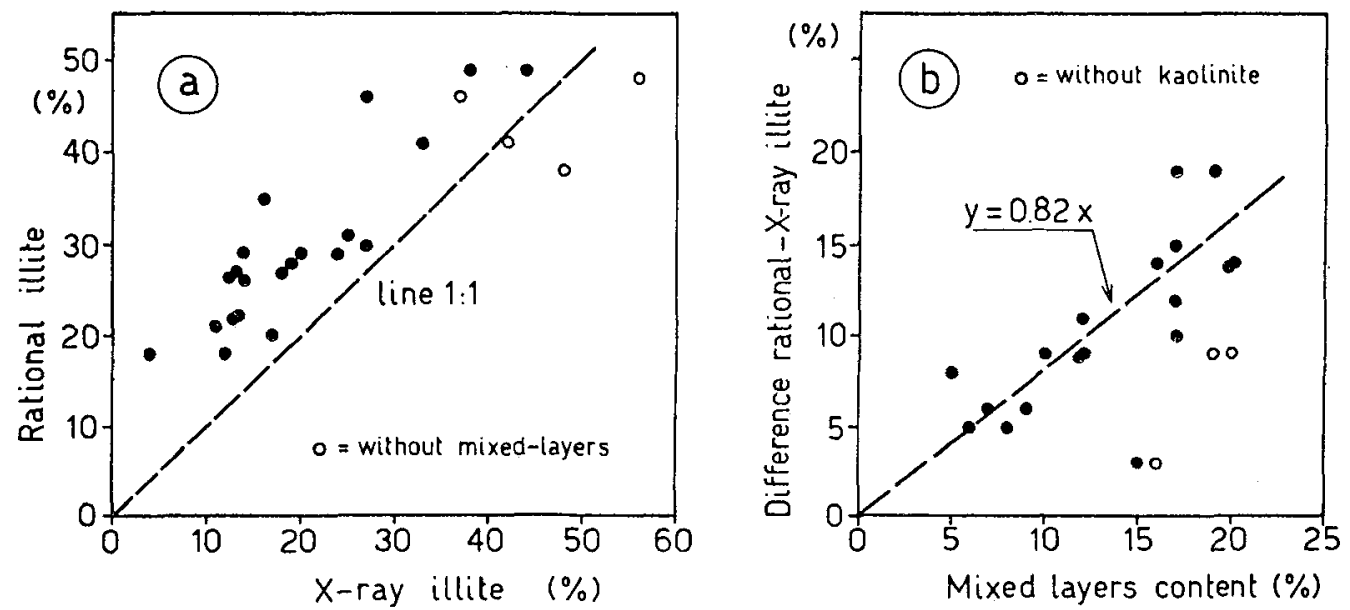

Fig. 2 - a) Comparison between $x$-ray and rational illite data determined in kaolinitic and smectitic clays; b) Difference between rational and $x$-ray data for $i\rceil-$ lite concentrations vs. mixed-layers content in kaolinitic and smectitic clays.

\section{REFERENCES}

1/ Krajewski, A., Fabbri, B., Fiori, C. and Valmori, R., Ceramica Informazione 20 (1985) 391.

$\overline{12} /$ Paganel1i, L. and Tiburtini, R., Miner. Petrogr. Acta 10 (1964) 57.

/3/ Fiori, C., Vincenzini, P. and Ortelli, G., La Ceramica 27 (1974) 13.

14/ Thorez, J., Practical identification of clay minerals. A handbook for teachers and students in clay mineralogy. Ed. Lelotte, Dison, 1976.

15/ Krajewski, A., Fabbri, B., Fiori, C., Valmori, R. and Tenaglia, A., C.N.R., IRTEC, internal report $n .85 / 249$.

16/ Wiegmann, J.; Horte, C.H. and Kranz, G., Proceedings of the VII International Clay Conference 1981, Ed. by H. Van Olphen and F. Veniale. Elsevier Scientific Publishing Company, Amsterdam - Oxford - New York, 1982. 